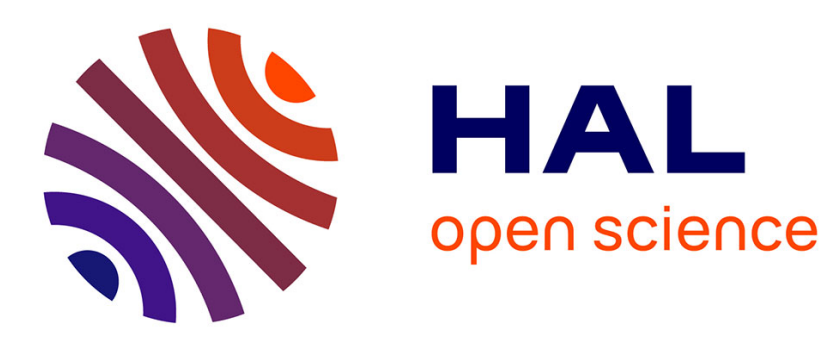

\title{
The Modularity of the 'Revolutionary' Repertoire of Action in Egypt: Origins and Appropriation by Different Players
}

\author{
Clément Steuer
}

\section{- To cite this version:}

Clément Steuer. The Modularity of the 'Revolutionary' Repertoire of Action in Egypt: Origins and Appropriation by Different Players. Social Movement Studies, 2017, 17 (1), pp.113-118. 10.1080/14742837.2017.1377602 . hal-02315954

\section{HAL Id: hal-02315954 \\ https://hal.science/hal-02315954}

Submitted on 15 Oct 2019

HAL is a multi-disciplinary open access archive for the deposit and dissemination of scientific research documents, whether they are published or not. The documents may come from teaching and research institutions in France or abroad, or from public or private research centers.
L'archive ouverte pluridisciplinaire HAL, est destinée au dépôt et à la diffusion de documents scientifiques de niveau recherche, publiés ou non, émanant des établissements d'enseignement et de recherche français ou étrangers, des laboratoires publics ou privés. 


\title{
The Modularity of the 'Revolutionary’ Repertoire of Action in Egypt: Origins and Appropriation by Different Players
}

\author{
Clément Steuer, Oriental Institute (ASCR).
}

\begin{abstract}
:
The Egyptian 'revolutionary' repertoire of action, that is to say the repertoire used by the protesters of January 2011, was characterized by a combination of several features: occupation of a symbolic place; 'horizontal' forms of organization; recourse to new electronic information and communication technologies (especially social networks); and rhetoric centered around universal values such as dignity, social justice, human rights and democracy. This repertoire was born as a result of the merging of two parallel cycles of mobilization, which had actually started during the previous decades, one animated by activists from the educated middle class, and the other by workers struggling for economic and social reforms. After the fall of Hosni Mubarak in February 2011, it demonstrated its extreme modularity, being appropriated by different players from all sections of the political spectrum, from the Salafist hāzimūn to proponents of the military power.
\end{abstract}

Keywords: Egypt, revolution, repertoire of action, modularity, labor movement, youth movement

\section{Notes on Contributors}

Clément Steuer ( $\mathrm{PhD}$, University of Lyon) is a political scientist, and a researcher at the Oriental Institute of the Academy of Sciences of the Czech Republic. He has published in a wide variety of academic journals and edited volumes, especially on issues related to the Egyptian politics.

The Egyptian protest movement of January 2011, which led to the ousting of president Hosni Mubarak, has become almost paradigmatic, inasmuch as scholars have begun to use it to describe other protest movements which occurred thereafter in places as diverse as North America (Kerton, 2012) and India (Chatterji, 2013). The most prominent feature of the 25 January uprising was probably the peaceful occupation of a particular square, which symbolized the national dimension and the revolutionary nature of the movement. 
Over the past six years, Tahrir Square has been mirrored in many places (for instance: Yemen, Bahrain, Spain, US, Turkey, France) This phenomenon was actually anything but new when it took place in 2011 (McCurdy, Feigenbaum, \& Frenzel, 2016), but the novelty came from its association with some additional features: non-hierarchical, 'horizontal' forms of organization; recourse to on-line social networks; and rhetoric centered around universal values. Altogether, these various features created a 'revolutionary' repertoire of action, which was distinct from previous Egyptian repertoires, even though it was based on them. I will retain here the minimalist definition of repertoire advanced by Charles Tilly: 'a limited set of routines that are learned, shared, and acted out through a relatively deliberate process of choice' (1995, p. 42). A particular repertoire is the historical product of years of struggle, and exists between a particular group of protesters and a political regime.

The Egyptian revolutionary repertoire coexisted with other forms of protest-sometimes more violent, as was the case on 28 January 2011, particularly in Suez, or as used by the football 'Ultras' (Woltering, 2013)-but constituted what could be described as a dominant model, this dominance being highlighted by the way it has been since imitated, both in Egypt and in many other places around the world. Indeed, this repertoire has demonstrated its extreme modularity, within the context of the opening-up of the political arena and the rolling back of the influence of the security apparatus over a two and a half year period. I am following here the classical Tarrow definition of modularity: 'the capacity of a form of collective action to be utilized by a variety of social actors, against a variety of targets, either alone, or in combination with other forms' (1994, p. 33). The revolutionary repertoire proved to be modular in nature, encompassing what Takeshi Wada calls the 'four dimensions of transferability': actors, targets, issues and locations (2012, p. 550). Regarding the dimension of the actors, especially, this repertoire has shown an important modularity, since it has been appropriated not only by part of the Islamists, but also by some of the proponents of the old regime. Yet, in a given society, a set of tactics is usually almost exclusively used by certain groups. When another group starts to use this set of tactics, it could result in a failure of this protest movement, or in a 
restructuring of the "division of protest" (Orkibi, 2017). Using the example of the Israeli demobilized reservists' protest in the 1970s, Eithan Orkibi argues that the appropriation, by the mainstream society, of a repertoire hitherto affiliated with marginal and radical groups contributes to its legitimization (ibid.) We will see, through the Egyptian case, that this assertion is highly dependent of the context, and that such an appropriation can sometimes results in the opposite.

In this paper, I discuss the origins and main features of such a repertoire, as well as its development and modularity within the national Egyptian arena from 25 January 2011 to 30 June 2013. I conclude with an evocation of the possible abandonment of this repertoire by Egyptian protesters.

\section{Historical origins and main features}

The Egyptian revolutionary repertoire was born as a result of the merging of two previously existing repertoires: the 'civil-democratic' (De Smet, 2014) repertoire and the 'workers' one. Both of them developed as the result of two parallel cycles of mobilization that had consolidated and structured themselves over the previous decade: the first one was created by activists from all shades of the political spectrum, who made claims for more democracy and political openness, and the second one was used by the industrial workers, who protested against neo-liberal economic reforms. They have long been described as opposite and complementary movements, the first one associated with political claims and the second with bread-and-butter demands (Shahāta, 2010). But, actually, both of them were political and social at the same time: on the one hand, the mobilized workers made political claims as early as 2007 (Beinin, 2011), and, on the other hand, the civil-democratic movement was animated by activists from the educated middle class, who felt as much threatened by precarity as the workers did (Duboc, 2011).

The 2000s witnessed the birth of several initiatives that brought together activists from across the full political spectrum (in solidarity with the Palestinian Intifada in 2001, against the invasion of Iraq in 2003). In 2004, these movements began to challenge the political order, with the creation of the National Movement for Change (Kifaya), which 
aimed at preventing a renewed mandate for Hosni Mubarak (Vairel, 2006). During that time, the youth movement began to gain autonomy (creation of the 'Youth for Change'), and made its first attempt to connect with the labor movement four years later, in 2008.

The latter had been propelled by the acceleration of neo-liberal reforms that had been enacted since 2004. In October of that year, the workers from the ESCO Spinning Company began a strike in order to protest against the privatization of their factory, and obtained some economic gains. Most importantly, this strike established that the state would not seek to exercise violent repression against striking workers, as it had before. This success opened up the doors for other workers (Beinin, 2011, p. 192). In December 2006, another strike erupted in the city of Mahalla. Once again, workers achieved substantial gains. However, the largest mobilization of this period was not organized by blue-collar workers, but by real estate tax collectors employed by local authorities. In the fall of 2007, they claimed-and obtained-wage parity with their colleagues working directly for the Ministry of Finance. Their movement involved strikes, civil disobedience, demonstrations, and finally an eleven-day sit-in in front of the Ministry (Beinin, 2011).

These two kinds of social movement shared a core set of common features. Firstly, they were organized outside the boundaries of political parties or other official institutions, such as the trade unions. Challenging the policies of the regime, and without support from the Egyptian Trade Union Federation, which was closely controlled by the state and the ruling party, the workers relied mainly on informal, local networks (Beinin, 2009; Duboc, 2011). The second feature shared by all these protest movements was the emphasis on universal values, expressed in terms of 'rights', which had been brandished since the 1980s, not only by the civil-democratic movements (El Khawaga, 2003), but also by the struggling workers (Stork, 2011).

In January 2008, the strike committee of the Ghazl Al-Mahalla company called for a national strike on 6 April, in support of a claim to establish a minimum monthly wage. During the previous weeks, young middle class activists had been using blogs and social networks in order to show solidarity with the workers of Mahalla. Although this particular mobilization was largely a failure, it constituted the first major attempt to build 
a link between the workers and the mobilized middle class youth movement (Cole, 2012, pp. 488-489), and it gave birth to one of the most important youth organization, the 6 April Youth Movement, which played a key role during the 2011 revolution. In addition, the 2008 solidarity initiative saw the first use of on-line social networks in order to organize protest movements in Egypt. This latter protest tool constitutes another of the main features of the revolutionary repertoire (Allam, 2014).

This repertoire is characterized by the combination of all the above-mentioned features, as well as the occupation of a symbolic place. However, even this latter characteristic has a history, which can be traced back to the development of the two kinds of mobilization described above. Demonstrations were organized in Tahrir Square as early as 2001 in support of the Palestinian people (Vairel, 2006). Besides this, occupations have been a traditional tool used in the Egyptian workers struggle since at least the 1970s (Beinin, 2011). Moreover, demonstrations were conducted in 2008 in the main square of Mahalla. Indeed, although Tahrir Square became the major battlefield during the 2011 uprisingsymbolizing the national dimension of the movement-other squares were occupied in the same way in many parts of the country.

\section{Developments and modularity within the national arena}

Repertoires of contention are built historically, through social and political struggles (Tarrow, 1993), and the above-mentioned workers and civil-democratic repertoires evolved over decades, before converging around 2009-2010 and giving birth to the revolutionary repertoire. The latter continued to evolve thereafter, due to the change of the regime. Meanwhile, it has also been appropriated by other players, whose claims are very different-not to say totally opposite-from those of the revolutionaries.

During the 2011 uprising, the movement was animated by actors emerging from the cycles of mobilization described above: the 6 April Movement called for a demonstration on 25 January, along with Kifaya and other youth organizations. Moreover, on 30 January, in Tahrir Square, some independent trade-unionists announced the formation of an ‘Egyptian Independent Trade Union Federation’ (Clément, Duboc, \& El Shafei, 2011). 
Then, during the first few months following the ousting of Mubarak, Tahrir Square was regularly occupied by the same actors, demanding the fulfillment of their social and political claims But during that time, with the workers movements staying focused mainly on the social and economic claims- advocating 'substantive democracy' (Beinin, 2012)-the middle-class activists mobilized principally in favor of constitutional and political reforms (Cole, 2012, p. 506 ; Brecht, 2014, pp. 30-31).

The dominant repertoire of the revolutionaries remained the same, at least until JanuaryFebruary 2012 (Gerbaudo, 2012, pp. 13-14), and this preeminence of the 'Tahrir' model, at a time when the political situation was quickly evolving, probably contributed to the weakening of the movement. Nevertheless, innovative forms of activism started to appear at the same time, and even more so under the rule of Muhammad Morsi: the use of artistic expression, the organization of human chains, 'civil disobedience' on the scale of whole cities... (Stadnicki, 2013).

Meanwhile, Islamist and old regime forces sought to appropriate the revolutionary legitimacy, beginning with the revolutionary repertoire. On 29 July 2011, the Muslim Brotherhood and the Salafist Nur party occupied Tahrir Square, demanding the establishment of a religious state. These forces sometimes demonstrated with revolutionaries, as was the case on 18 November 2011, or in June 2012, in order to remind the army leaders of their promise to pass power to officially elected civilians. However, they remain hierarchical centralized organizations, which have always failed to appropriate any features of the revolutionary repertoire, other than the occupation of Tahrir Square and the use of a 'revolutionary' rhetoric.

The most extreme example of the appropriation of the revolutionary pattern by Islamist activists is the appearance of the decentralized and very informal hāzimūn movement, which adopted all the features of the revolutionary repertoire described above. The designation hāzimūn means 'determined people', but at the same time it is a reference to the first name of the tutelary figure of this movement, the 'revolutionary sheikh', Hazim Salah Abu Ismail (Lacroix \& Shalata, 2016). In April 2012, the followers of the latter occupied Tahrir Square night and day for several weeks. They even eclipsed the 2012 
Workers' Day celebration, when only a few dozens of leftists and unionists gathered in Tahrir. Due to the massive Salafist presence at the center of the square, leftist demonstrators remained confined to an area in front of the doors of the central administration building.

The revolutionary repertoire has been progressively appropriated by proponents of the military power as well. Firstly, the latter tried to occupy alternative squares, as a symbol of their opposition to the revolutionary and/or Islamist claims. Thus, in November 2011, as the youth movements were occupying Tahrir Square and violently confronting the police in Muhammad Mahmud Street, the pro-military forces were demonstrating a few miles away in the Abbaseya neighborhood. In the same way, in June 2012, between the end of the presidential election and the official proclamation of the results, the supporters of Muhammad Morsi were in the process of occupying Tahrir Square, when the followers of his rival-General Ahmad Shafiq-were gathering at the memorial of the Unknown Soldier in Nasr City.

A few months later, under the rule of Muhammad Morsi, the pro-military forces were able to gain some revolutionary legitimacy, namely by supporting the claims of the workers and the youth movement, who were both opposed to Muslim Brotherhood rule. A new youth organization was created during the spring of 2013, calling for early presidential elections. This new movement, Tamarrod, shared all the features of the revolutionary repertoire. Founded by young Nasserites, it gained the official support of many revolutionary organizations, such as Kifaya and the 6 April Movement, but also of businessmen-such as Naguib Sawiris, a telecoms tycoon and the founder of the Free Egyptian party-, and even of the deep state (Hubbard \& Kirkpatrick, 2013; Barbary \& Adib Doss, 2014). It called for massive demonstrations on 30 June 2013, which resulted in the ousting of Morsi by the military, four days later.

\section{Conclusion}

Since the ousting of Muhammad Morsi, both revolutionaries and Islamist activists have lost control of Tahrir Square. On 25 January 2014, the symbolic place was occupied by 
pro-Sisi demonstrators, demanding that their champion should run for president. After the bloody dispersal of the Rabaa and Nahda sit-ins in August 2013, the supporters of former president Muhammad Morsi organized many demonstrations in many places-including university campuses-but never in Tahrir Square. Since the adoption of the protest law in November 2013, the revolutionary youth organizations have faced similar conditions, with small groups gathering for a few moments in different places before dispersing. They seem to have returned to the pre-revolutionary repertoire, when they were racing 'through the streets of Cairo attempting to find an open space to gather' (Vairel, 2011, p. 41). Currently, it feels as if the reconstitution of the security apparatus, as well as the need to distance themselves from the Islamists, has made the revolutionary repertoire obsolete for the secular opponents of the Egyptian regime, at least for the time being. Many of them now appear to favor the pursuit of local initiatives with concrete immediate objectives and, in the foreseeable future, do not see any opportunities for nationwide actions aimed at regime change. Nevertheless, following a short respite during the second semester of 2013, social unrest has continued to erupt from time to time in different sectors.

Then, if the revolutionary repertoire proved itself extremely modular-regarding especially the dimensions of the locations and the actors-it appears at the same time as being very dependent of the context, since it was used only for a relatively short period of time (two years and half). How can we interpret the abandonment of this repertoire? We can see it as a mere outcome of a shift in the structure of political opportunities, but we can also argue that it is due to the restructuring of the Egyptian "division of protest": this repertoire eventually proved itself inefficient for the revolutionary activists, but also for the Islamists. And regarding the pro-military activists, if they succeeded while using this repertoire, they do not need it anymore, since they do not have any reasons to take the street for the current period. Then, the appropriation of this set of tactics by the mainstream society did not result in its legitimization. On the contrary, this repertoire was widely perceived as legitimate during the 2011-2013, and the counter-revolutionary groups appropriated it because of this legitimacy and the legitimacy of the 2011 
revolution. In so doing, they contributed to de-legitimatize not only this repertoire, but also the founding moment it was associated with.

\section{References}

Allam, N. (2014). Blesses and curses: Virtual dissidence as a contentious performance in the Arab Spring's repertoire of contention. International Journal of Communication, 8, 853-870.

Barbary, C., \& Adib Doss, M. (2014). Tamarrod (« rébellion ») : une autre lecture de l'action politique dans le processus révolutionnaire égyptien [Tamarrod ('rebellion'): another reading of the political action in the Egyptian revolutionary process]. Confluences Méditerranée, 88, 155-169.

Beinin, J. (2009). Workers' protest in Egypt: Neo-liberalism and class struggle in 21st century. Social Movement Studies, 8, 449-454.

- (2011). A workers' social movement on the margin of the global neoliberal order. Egypt 2004-2009. In J. Beinin \& F. Vairel (Eds.), Social movements, mobilization and contestation in the Middle East and North Africa (pp. 181-201). Standford, CA: Standford University Press.

- (2012). Egyptian workers and January 25th: A social movement in historical context. Social Research, 79, 323-348.

Chatterji, M. (2013). The globalization of politics: From Egypt to India. Social Movement Studies, 12, 96-102.

Clément, F., Duboc, M., \& El Shafei, O. (2011). Le rôle des mobilisations des travailleurs et du mouvement syndical dans la chute de Moubarak [The role of the workers mobilizations and of the unionist movement in the fall of Mubarak]. Mouvements, 66, 6978.

Cole, J. (2012). Egypt’s new left versus the military junta. Social Research, 79, 487-510. 
De Smet, B. (2014). Revolution and counter-revolution in Egypt. Science \& Society, 78, 11-40.

Duboc, M. (2011). La contestation sociale en Égypte depuis 2004. Précarisation et mobilisation locale des ouvriers de l'industrie textile [The social contestation in Egypt since 2004. Casualization and local mobilization of the workers in the textile industry]. Revue Tiers Monde, Special issue, 95-115.

El Khawaga, D. (2003). La génération seventies en Égypte. La société civile comme répertoire d'action alternatif [The 1970s generation in Egypt. The civil society as an alternative repertoire of action]. In M. Bennani-Chraïbi \& O. Fillieule (Eds.), Résistances et protestations dans les sociétés musulmanes (pp. 271-292). Paris: Presses de Sciences Po.

Gerbaudo, P. (2012). The impermanent revolution: The organizational fragility of the Egyptian prodemocracy movement in the troubled transition. Social Justice, 39, 8-23.

Hubbard, B., \& Kirkpatrick, D. D. (2013, July 10). Sudden improvements in Egypt suggest a campaign to undermine Morsi. The New York Times. Retrieved from http://www.nytimes.com/2013/07/11/world/middleeast/improvements-in-egypt-suggesta-campaign-that-undermined-morsi.html

Kerton, S. (2012). Tahrir, here? The influence of the Arab uprisings on the emergence of Occupy. Social Movement Studies, 11, 302-308.

Lacroix, S., \& Shalata, A. Z. (2016). The rise of revolutionary Salafism in post-Mubarak Egypt. In B. Rougier \& S. Lacroix (Eds.), Egypt's revolution: Politics, religion, and social movement (pp. 163-178). New York City: Palgrave Macmillan.

McCurdy, P., Feigenbaum, A., \& Frenzel, F. (2016). Protest Camps and Repertoires of Contention. Social Movement Studies, 15, 97-104.

Orkibi, E. (2017). Resisting the cultural division of protest: The Israeli demobilized reservists’ protest after the Yom Kippur War (1973-1974). Cultural Dynamics, 29, 23-38. 
Shahāta, D. (Ed.). (2010). 'Awda al-siyāsiya. Al-harakāt al-ihtijājiya al-jadīda fī Misr [The return of politics. The new social movements in Egypt]. Cairo: Center for Political and Strategic Studies.

Stadnicki, R. (2013). De l'activisme urbain en Égypte : Émergence et stratégies depuis la révolution de 2011 [Urban activism in Egypt: Emergence and strategies since the 2011 revolution]. Echo Géo, 25. Retrieved from http://echogeo.revues.org/13491

Stork, J. (2011). Three decades of human rights activism in the Middle East and North Africa. An ambiguous balance sheet. In J. Beinin \& F. Vairel (Eds.), op. cit. (pp. 83-106).

Tarrow, S. (1993). Cycles of collective action: Between moments of madness and the repertoire of contention. Social Science History, 17, 281-307.

- (1994). Power in movement. Social movements, collective action and politics. Cambridge: Cambridge University Press.

Tilly, C. (1995). Popular contention in Great Britain, 1758-1834. Cambridge, MA: Harvard University Press.

Vairel, F. (2006). Quand ‘Assez !'ne suffit plus [When ‘Enough!' is no longer enough]. In F. Kohstall (Ed.), L’Égypte dans l'année 2005. Cairo: Cedej.

- (2011). Protesting in authoritarian situations. Egypt and Morocco in comparative perspective. In J. Beinin \& F. Vairel (Eds.), op. cit. (pp. 27-60).

Wada, T. (2012). Modularity and transferability of repertoires of contention. Social Problems, 59, 544-571.Woltering, R. (2013). Unusual suspects: 'Ultras' as political actors in the Egyptian revolution. Arab Studies Quarterly, 35, 290-304. 